\title{
«ET CEPENDANT LES BERBÈRES EXISTENT ». EL POBLAMIENTO BERÉBER EN LA FRONTERA SUPERIOR ANDALUSÍ (SIGLOS VIII-XII) Bilal Sarr
}

Alhulia. Granada, 2014.

157 Páginas. 12 Fotografías y 9 figuras. Blanco y negro.

Bilal Sarr es profesor contratado Ramón y Cajal en el departamento de Historia Medieval y Ciencias y Técnicas Historiográficas de la Universidad de Granada, así como responsable del proyecto I+D+i «Poblamiento e intercambios en torno al mar de Alborán (al-AndalusMagreb, siglos VIII-XV)» (HAR2014-56241-JIN). La obra que reseñamos se inserta dentro de la línea de investigación desarrollada por el autor en torno a los beréberes iniciada con el estudio de la taifa zirí de Granada y sus protagonistas, los beréberes Sinhaya, bajo el título La Granada Zirí (1013-1090).

Los beréberes o amazigues, como bien señala el autor, son un conjunto de pueblos que ocupaban desde tiempos remotos la práctica totalidad del norte de África, desde Siwa en Egipto hasta el océano Atlántico, incluyendo las islas Canarias, y desde el mar Mediterráneo hasta los límites meridionales del desierto del Sáhara. Se caracterizan por su carácter heterogéneo en las formas de hábitat, actividades económicas, creencias religiosas y grados de organización socio-política. De ahí la dificultad de reconstruir una cultura material genuinamente beréber, cuestión a la que nos remite el título del libro. Con esta frase, Et cependant les berbères existent ( $Y$ sin embargo los beréberes existen), el autor recoge lo ya planteado por el prehistoriador y antropólogo francés Gabriel Camps de que a pesar de las dificultades, los beréberes existen y es gracias a su lengua que formaron y forman parte de un grupo socio-cultural. Otra dificultad a tener en cuenta en esta línea de investigación es que, a excepción de los Mafajir al-Barbar, las fuentes no son beréberes y, en su mayor parte están cargadas de prejuicios en especial la crónica al-Muqtabis de Ibn-Hayyan, una de las más utilizadas. El autor realiza un repaso de la historiografía francesa y española sobre el tema beréber, recogiendo los autores y obras mas destacados para establecer un estado de la cuestión.

Como bien diría al-Maqqari, (Naft al-tib, vol. I, p. 244): "Los beréberes estaban cerca de al-Andalus, no les separaba nada más que cruzar el Estrecho, por lo que no paraban de llegar en masas". Desde un principio el contingente beréber fue muy superior al árabe en el proceso de conquista de la Península Ibérica y desde tiempos remotos existieron intercambios entre las dos orillas del Mediterráneo.

Esta obra tiene sus raíces en un proyecto de investigación posdoctoral en torno al poblamiento beréber en la Marca Superior de al-Andalus desarrollado entre
2011 y 2014. El marco geográfico objeto de análisis se encuentra en el noreste peninsular, Aragón y la parte occidental de Cataluña, aproximadamente los territorios de Tudela, Huesca, Barbastro, Lérida y Zaragoza.

La metodología de trabajo seguida ha sido la recopilación bibliográfica, la revisión de las fuentes escritas árabes y latinas, el análisis de la cartografía moderna e histórica y por último prospecciones arqueológicas y visitas tanto a yacimientos como a lugares con toponimia de origen beréber.

El libro presenta una amplia introducción a partir de la cual se divide en tres ejes temáticos:

1. Evolución histórica. En la que se realiza un análisis de las referencias halladas en las fuentes en relación a grupos amazigues desde la conquista musulmana de la Península Ibérica hasta el periodo post-andalusí.

2. Los datos arqueológicos arrojados por las prospecciones y visitas de campo llevadas a cabo. Se realiza una reflexión sobre la cuestión de una arqueología beréber o de los asentamientos con toponimia beréber decantándose por la segunda opción, lo que el autor justifica en las conclusiones. De todos, destacan dos asentamientos principales como son Mequinenza y Lizana ambos situados junto a ríos.

3. La sociedad. Se estudian los orígenes tribales, los grupos sociales y se dedica un apartado a sabios y personajes beréberes de la zona objeto de estudio. Se incluye un mapa y un cuadro que relaciona topónimos, tribus y origen geográfico.

En el apartado de conclusiones, el autor hace una reflexión en torno a las incógnitas planteadas en un principio e intenta aportar respuestas.

La obra cuenta con una extensa y completa bibliografía compuesta por fuentes árabes, latinas y obras de obligada consulta para el estudio de los beréberes y de al-Andalus.

No es una obra muy extensa pues se centra en la Marca Superior, hubiese sido importante ampliar aún más el estudio al resto de al-Andalus y profundizar en aspectos arqueológicos contando con un capítulo dedicado al estudio de materiales en la medida de 
lo posible. Aún así reconocemos el esfuerzo llevado a cabo ante las dificultades admitidas por el autor frente al estudio de un grupo social confundido y relegado a un segundo plano y por tanto carente de protagonismo en las fuentes escritas.

Es apropiado plantearse, como se ha hecho en las conclusiones, que ante la heterogeneidad de los beréberes llegados a la península los patrones de asentamiento no tenían por qué ser los mismos que tradicionalmente se había considerado, relegándoles a zonas montañosas frente a la aristocracia árabe que escogería las mejores tierras. En este sentido hay que destacar la aportación valiosa que supone esta obra al conocimiento de una zona que, hasta el momento, había despertado poco interés con respecto a los estudios beréberes y el acierto de explicar la relación existente entre topónimos, tribus y origen geográfico.

Encarnación Reyes Martínez. Universidad de Granada 